This item was submitted to Loughborough's Research Repository by the author.

Items in Figshare are protected by copyright, with all rights reserved, unless otherwise indicated.

\title{
Regional planning is dead: Long live planning regional futures
}

PLEASE CITE THE PUBLISHED VERSION

https://doi.org/10.1080/00343404.2020.1750580

PUBLISHER

Taylor \& Francis (Routledge)

VERSION

AM (Accepted Manuscript)

PUBLISHER STATEMENT

This is an Accepted Manuscript of an article published by Taylor \& Francis in Regional Studies on 4 May 2020, available online: http://www.tandfonline.com/10.1080/00343404.2020.1750580.

\section{LICENCE}

CC BY-NC-ND 4.0

\section{REPOSITORY RECORD}

Harrison, John, Daniel Galland, and Mark Tewdwr-Jones. 2020. "Regional Planning Is Dead: Long Live Planning Regional Futures”. Loughborough University. https://hdl.handle.net/2134/12061035.v1. 


\title{
Regional Planning is Dead: Long Live Planning
}

\section{Regional Futures}

\author{
John Harrison', Daniel Galland², Mark Tewdwr-Jones ${ }^{3}$ \\ ${ }^{1}$ Geography and Environment, Loughborough University, UK, j.harrison4@lboro.ac.uk \\ ${ }^{2}$ Department of Urban and Regional Planning, Norwegian University of Life Sciences, Norway, \\ daniel.galland@nmbu.no
}

${ }^{3}$ School of Architecture, Planning \& Landscape, Newcastle University, UK, $\underline{\text { mark.tewdwr- }}$ jones@newcastle.ac.uk

Regional Studies 2020

DOI: $10.1080 / 00343404.2020 .1750580$

\begin{abstract}
This paper starts from the premise that regional planning as we have known it is now defunct and something we need to get used to. Identifying those disruptive elements that have undermined traditional forms of institutionalised regional planning, we argue that contemporary planning debates are too obsessed with the institutional planning frame and have become distracted from the changing content of the real-world picture. Our aim in this paper is to reassert the purpose and values of planning by rediscovering the content, conceptualise multiple and fluid forms of planning frames, and reposition the planner as an orchestrator and enabler of planning regional futures.
\end{abstract}

Key words: Regional planning; regional futures; wicked problems; agile planning JEL codes: O21 R58 


\section{Introduction: It's the End of Regional Planning as we Know It (and We Feel Fine)}

Our aim in this paper is to re-energise planning debates in regional studies. This is despite our somewhat less optimistic starting point, which is a contention that regional planning as we know it is now defunct and something we need to get used to. But let us be clear from the outset. This is not as it may first appear a one-way critique of regional planning and by implication the history of planning within regional studies, one written with all the benefits of hindsight. What it is instead is a provocation of a different sort. It is a provocation that amounts to a first step towards forecasting a more positive future for planning in regional studies, albeit one which is very different in style, approach and purpose. Rather than defend or try to reclaim that which has been lost with the decline of institutionalised forms of regional planning, our motivations centre on forging new ways of planning regional futures. For us, this is about recovering the very essence, purpose and values of planning. It is about bringing these to bear on the wicked problems affecting regional futures. It is to say that regional planning was of its time, but that time is not now. It is to claim that much of what we associate with this era - the all-encompassing geographically fixed grand plan, uniformal approaches, formally institutionalised planning, planners as kingmakers - is best remembered as a relic of an age which is passing or has already passed. What interests us is what is relevant to today's needs and those which lay ahead. It is here that planning's future in regional studies should be debated.

To shift the horizons for planning in regional studies, we start by identifying those disruptive elements which have undermined traditional forms of institutionalised regional planning, developing an argument that contemporary planning debates have become too obsessed with the institutional planning frame and distracted from the changing content of the real-world picture 
(Section 2). For our part, we seek to reassert the purpose and values of planning by rediscovering the content, conceptualise multiple and fluid forms of planning frames, repositioning the planner as an orchestrator and enabler of planning regional futures (Section 3). In the concluding part (Section 4), we reflect on how our vision challenges conventional understandings for the future of planning cities and regions.

\section{Why Planning? Why Regions? Why Now?}

\subsection{Planning}

The hallmark of planning is that it is "a professional and highly politically contentious process attempting to make sense of the drivers of change that have land use effects geographically, against short-, medium- and long-term trends, within changing governing structures, and individual and collective expectations that have social, economic and environmental implications that change over time" (Tewdwr-Jones, 2012: 4). If this is the hallmark of planning per se, the adjectives that precede 'planning' alert us to multiple understandings that emerge from different planning traditions (most notably, positivist planning with the statutory land-use plan as the yardstick and regulation as the model of implementation vs. interpretative approaches, which are less about the plan and implementation, focusing instead on placemaking strategies, relational processes and spatial governance) and planning styles (1950s 'rational', 1960s 'advocacy' and 1970s 'radical' from the US; 'communicative', 'collaborative' and 'deliberative' from Europe and North America since the 1990s; 'post-political' and 'agonistic' emerging in the 2000s) (Davoudi, 2012; Allmendinger, 2017; Fainstein and DeFillipis 2016). Each emerges from its own context, generates its own definition and meaning of what planning is, and then the spatial scales at which this mode of planning occurs, the role of the planner and the plan therein, and the methods and skills required to do planning. Today, and looking ahead, approaches focusing attention on 
multiculturalism, decolonisation and informality are leading to ever more diverse perspectives on what planning is and should be (Gunder et al., 2018).

With planning being an activity of the public, private and third sectors, different aspects of planning occur at different geographical scales, formulated, regulated or implemented by different governance actors. Let us not forget that in the early $20^{\text {th }}$ century, planning in Western countries was characterised by informality and very localised arrangements, often operationalised by individual architects or local governments, acting where there was a justifiable need for intervention (Hall, 2014). Only as time progressed, and people understood growing relationships between adjacent places, did ideas about regional planning begin to emerge (Geddes, 1915). In an array of contexts in the Global North, it was only in the mid-to-latter half of the $20^{\text {th }}$ century that planning became an institutionalised activity of the state in its various guises, shaped by statute and associated with the conferment of legal rights and responsibilities to defined, geographically fixed administrative or government units.

What was an activity of the central state in the mid-20th century soon became an activity of multiple levels of government, shared between the central and local state. As the decades passed, so the governing framework of planning changed and adapted to suit political ideological preferences. Nations have flirted with these changing scales and revised institutional forms of government (and therefore with planning) throughout the last hundred years, as different governments prioritised different scales of policy- and decision-making, not in a linear way but often moving forward then doubling back to previous older forms and recognisable governing structures, depending on global economic changes, ideological preferences on the part of the governing political party, and the needs of individual nations and regions. 
Governments may pursue planning through national action and policy, through sub-national mechanisms or, in the case of federal nations, through separate legal and policy arrangements (Knaap et al., 2015). What may be regarded as national and regional planning issues may be matters of national and regional significance (such as the provision of infrastructure) but it may also refer to nationally and regionally important issues that are delegated to subnational government (such as the operation of the planning system of development regulation). Equally, regional planning is not a static or single entity: it largely depends on the nation being considered, the constitutional settlement in each country, the style of planning present, and the relationship to both national forms of planning and local planning conditions. As conditions and times change, so do successive reforms of the governing framework around planning, with historical roles of some governing scales retaining a legacy for newly emerging forms of planning tiers. Since the late 1990s this picture has been clouded by the emergence of governance and the market, alongside government, initiating policies, developing strategies and taking decisions on issues and in areas that perhaps had been undertaken previously by the state (Raco and Savini, 2019; Harrison, 2020).

At first glance, it is easy to believe that as time marches on, some ideas brought to bear in planning are new, whereas others have sometimes been tried before but are recycled in new times, in new guises and given new labels. The fact that planning has endured through all these changes is a remarkable testament to its resilience. An alternative perspective is that maybe planning is a useful political tool because it has become sufficiently adaptable to take on new agendas and preferences. Regional planning is therefore a much more dynamically-changing activity than is sometimes recognised, susceptible to changing political preferences and institutional reform even in individual nation states, as well as the consequence of changing regional needs. 


\subsection{Planning and regions}

During the second-half of the twentieth century the regional dimension to planning appeared selfevident: after all, there were regional plans, regional planners and regional planning. Integral to this was knowing what 'the region' was that was being planned, but there are two fundamental problems with this assumption. The first is spatial because as any student of regional studies can tell you, there are no regions out there waiting to be planned (Allen et al., 1998). Regions are constantly in a state of flux and yet much of twentieth century planning was fixated with the ideal of all encompassing, geographically fixed grand plans. In our fast-paced and volatile globalising world, regions increasingly take on multiple forms such that asking "What is a region?" has never been so redundant. Far more important is understanding how regions are being constructed, who or what is mobilising them, and most critically, to what end (Paasi et al., 2019). Planning is no different. Planners cannot assume the region in which, through which, or over which planning happens because the landscape is far more complex than ever before. Those traditional forms of longer-term planning with fixed plans that required time to prepare and adopt are also likely to be a relic of regional planning, not relevant to today's needs (Friedmann, 1993). To survive, planners and planning must adapt to a world comprising the unplanned - and decidedly messy configuration of multiple, overlapping, competing and contradictory spatial imaginaries (Paasi and Zimmerbauer, 2016).

The second problem is scalar because a hallmark of regional planning is that it has always been at the mercy of the two main elected tiers of government - national and local - as opposed to setting its own definitive agenda (Friedmann and Weaver, 1979). Regional planning was always caught between national government, for whom regional planning is the vehicle for implementing projects which have national and interregional significance, and local government, for whom regional planning is a way to address intraregional issues which have localised implications. In 
postwar welfare states, different styles of regional planning emerged in response to a dual problematique - indicative planning styles in response to increasing inequalities between regions (Friedmann 1963) and land-use control to mitigate the environmental consequences of urban sprawl in the automobile age (Glasson, 1974). The story of regional planning therefore owes much to where the power lies between national and local because this determines what can happen at the regional level (Kuklinski, 1970). More problematic than this, however, has been the constant challenge for regional planning of fusing two fundamentally different rationales (national - topdown - interregional vis-à-vis local - bottom-up - intraregional) for its existence, both of which appear contradictory (Haughton \& Counsell, 2004). The upshot is regional planning always took on nationally specific forms such that there is, and never was, one 'regional planning' so-to-speak. In a federal system, such as Germany or the United States, regional planning was always less at the whims of local and national government than in a non-federal system (e.g. the United Kingdom), while in more centralised authoritarian states such as China, regional planning is key to promoting growth, whereas in Britain the opposite discourse exists (Wu, 2015).

Context is important, but our argument is that while the window dressing is, and will always be, different in different contexts (sprawl, metropolitan regionalism, zoning in the US; greenbelts and new towns in the UK; natural resources in Venezuela and Chile, for example) the essential purpose of regional planning remains the same: capitalising on regional opportunities, dealing with regional problems. In other words, while the endpoint (the outcomes) and midpoints (the means, styles, mechanisms and focus) of regional planning are always going to be different, the starting point is the same, and that is place. A further important point is that our contention that regional planning is dead is not just limited to those contexts where fixation with administrative and institutionalized forms of "Regional Planning" has been eroded (e.g. the United Kingdom, Denmark and The Netherlands) (Roodbol-Mekkes et al., 2015). Regional planning may still exist in its institutionalised form across many countries, and indeed still soldiering on preparing regional 
plans, but the practise of regional planning is dead (at best on life support) because while it might exist in name it is powerless as a shaper of regional spatial change (Galland, 2012). We say powerless because it is insufficiently agile to deal with constant change and complexity, too susceptible to long periods of governmental preparation in a fast-paced modern world, undermined by administrative containment in a world of increased connection and flow, and a small player vis-à-vis more powerful arms of the state and market forces which can and will instantaneously undermine any instrument of regional planning, however, well legally fixed it is in those countries constitution.

\subsection{Planning, regions and futures}

Former, current and future institutionalised forms of regional planning have been, are being and will continue to be undermined by disruptive elements. Oftentimes perceived beyond the grasp of planning, the 'wicked' character of these disruptive issues is essentially reified as external, paradigmatic, ideological-motivated forces holding an intrinsic capacity to subvert, destabilise and ultimately erode regional planning. While it might be a truism that any unsettling of the essence and values of regional planning takes place within the scope of a larger political domain, we must similarly acknowledge the influence of three other parallel domains: economic (e.g. firm strategies, investment decisions, technological developments, labour dynamics), sociospatial (e.g. rising inequality and differentiation, increased population and migration) and socioenvironmental (e.g. pressures around climate-energy-water, food supply, aging, security) (see Galland et al., 2020).

Against this backdrop, changing institutional and policy landscapes have triggered the increasing use of ad hoc, incremental or project-led approaches in planning, oftentimes denoted by a confusing range of styles and the struggle to continually align actors. The scope and time elements of planning have respectively transitioned from comprehensive, spatial and long-termed 
approaches towards siloed, less spatial (or even spaceless) and short-termed perspectives. Planning policies articulated as forms of single policy interventions have gradually become cancelled out by other external interventions frequently lacking synoptic and systems thinking. Planning has consequently, steadily become subservient to other narrow interests and in doing so, has unreflectively cut and pasted policy ideas from other territories - adamant to take institutional and spatial histories into account (Stead, 2012). At the same time, there has been a progressive fragmentation of those doing "actual" planning (Raco \& Savini, 2019).

As the fortunes of institutions and policies ebb and flow so does the fate of formalised regional planning. Characterised by the primacy of the global market and its flows of investment, accelerated regional change is mobilised through the close alignment between real-estate markets and global financial capital (Savini \& Aalbers, 2016). Neoliberal reforms, policy interventions and readjustments increasingly allow for changes in legislation related to agricultural land and planning, facilitating the incorporation of public and communal land into real-estate markets. Through these mechanisms, the commercialisation of low-priced rural land enables the dispersed expansion of residential suburban, industrial and commercial, and infrastructural lands (Murat Güney et al., 2019), as well as service-oriented uses in large city-regions and increasingly intermediate ones in global North and South contexts (Schindler \& Kanai, 2019).

Mobilised and honed through the logic of global financial capitalism, financial real-estate development is facilitated through a myriad of instruments where only specific actors (banks, hedge funds and institutional investors) get to participate, pragmatically and swiftly materialised in the form of industrial and logistical parks, commercial centres, residential areas, gated communities, and transport infrastructure. Given their size and shape, these physical interventions deeply affect urban-regional dynamics through processes of accelerated dispersed expansion at the expense of the sustainability of smaller city regions. This increasingly results in 
the congestion of regional spaces as well as other sociospatial and environmental externalities. Surely we should all be concerned that many now hold the view that "planning is [only] good for some basic tasks of economic management, such as building big infrastructures, but is inferior to markets in seeing the future" (Storper, 2016: 247).

Adding to this, the crisis of representative democracy and the rise of alternative forms of democracy have further undermined the legitimacy of planning and fragmented the means through which these multiple agencies affecting and effecting regional change are held responsible for their actions (Allmendinger \& Haughton, 2019). If we recognise and accept that accountability operates along multiple dimensions, uses various mechanisms of performance, and requires various levels of organisational response, then planning is clearly facing an accountability crisis.

\subsection{Regions and planning at the crossroads: from institutionalised regional}

\section{planning to multiple forms of planning regional futures}

Twentieth century regional planning is dead and the form that twentieth century planning took expired with it as the pillars upon which it was constructed (structurally, ideologically, spatially) have been removed or severely weakened. As noted above this may be uncomfortable for those in places where institutional regional planning remains, or those who crave for its return, Moreover, it will present a challenge to those looking to the New Urban Agenda as a framework for shaping urban and regional futures, particularly across the Global South:

"§49 We commit ourselves to support territorial systems that integrate urban and rural functions into the national and sub-national spatial frameworks" 
"§72 We commit ourselves to long-term urban and territorial planning processes and spatial development practices" (UN-Habitat, 2017)

A new urban agenda it may be, but old regional planning it is - territorial, top-down, long-term. So where next?

Regional planning is at a crossroads. One option is to carry straight on, adopt a stoic businessas-usual mentality, and try to ignore how regional planning is dead (or dying) in places which have actually done regional planning. Another option is to turn-off and head in the direction adopted by the New Urban Agenda, presenting old-style regional planning as somehow 'new', but this path will quickly become bumpy and reach another dead end (Watson, 2019). The third option is to turn-off in a different direction altogether - what we present here as 'planning regional futures'.

We may have reached the end of Regional Planning as we know it but rather than feel sorrow or nostalgic about this, we have a renewed sense of hope that the multiple forms regional planning now takes offer a far more optimistic outlook for planning regional futures. We are optimistic because we see planning becoming more, not less, important. This rests on seeing planning as an entity, not all of which is - or should be - professionalised and institutionalised as 'Planning'.

Our proposition is simple: we need to recognise the world for what it is, not as it once was, and to plan accordingly. To do this we must direct our attention back toward the content of the picture rather than the institutional frame which we have become increasingly fixated with. 


\section{For a New Planning of Regions}

\subsection{Reasserting the purpose and values of planning}

The case for initiating any form of regional planning stems from a desire to deal with major externalities associated with the growth or decline of places, most often urban areas. That has always been the hallmark of regional planning. Alongside rapid urbanisation, a requirement to analyse changing social, economic, environmental and technological changes, spatial connectivity and differentials between neighbouring places, and a need to propose phased and resourced essential infrastructure, have all necessitated a more-than-local, regional, response. The task of relying on regional planning to analyse trends and create a political and resourced programme of action is the very essence of planning. Or at least it should be.

Let us not forget that the Garden City Movement that emerged in the UK and the City Beautiful Movement in the United States came about precisely because of a desire to address how we live, the need to address social plights of the most vulnerable in society, and the externalities of industrial development (Howard, 1902). Moreover, Patrick Geddes, who influenced planning with its working method of survey the region, analyse, and finally - and only then - plan, was premised on the idea of place-to-place interrelationships, connectivity and infrastructure links (Geddes, 1915). Geddes' evolutionary urbanism was part developmental, part evolutionary and part environmental, linking social processes to physical forms, but that cities should be studied in the context of the region. What this reminds us is the development of regional plans, more commonly referred to as regional reports, in the 1910 s and 1920 s occurred in an ad hoc, place-specific way, to address economic decline and unemployment. Not one of these pivotal moments in the emergence of regional planning occurred because there was a regional government or set of nationally-determined institutions to perform it. And yet, in the second half of the twentieth century, 
as soon as regional planning gradually institutionalised through standardised nationally-imposed frameworks and forms covering larger administrative areas, planners lost some of the raison d'être for having regional planning. Planning forgot that regional planning was meant to be there to serve a wider purpose, rather than to see it as just another administrative tier of institutional forms and one-size-all responses (Rydin, 2011).

It is little wonder that constant arguments have materialised since this time between national and subnational actors - centred around differentials in top-down funding allocations, infrastructure spending, new housing development numbers - and within national governments. Against this constant game of regional political football, politicians have resorted to seeing the means - the tools and forms of regional planning - in all their flawed glory, as the real problem at hand. It is an easy if somewhat lazy response to make. Planners, too, have tended to resort to arguing over the institutional and political forms of regional planning, lamenting their loss, or loss of status and reformulation, rather than address regional specific place needs (Watson, 2009). The result is the regional has often been seen as a convenient, if troublesome, tier of administration, drawing constantly on national funding resources and operating at arm's length of government (Brenner, 2003; Allmendinger \& Haughton, 2007).

And so we come full circle: planners and planning advocates aided and abetted by national government welfarist policies accelerated regional planning from a spatially-selective activity where it was needed, into an institutionalised and standardised bureaucratic machine that became divorced from place needs and increasingly resented (Hall \& Tewdwr-Jones, 2020). Over 100 years after Geddes, we can still identify a range of social, economic, environmental and technological problems that places are experiencing, and we recognise that those problems take on different degrees of importance or relevance in different places, affected by circumstances of place and history and policy intervention. We also recognise that places change as much due to 
relational changes outwith a place as the drivers of change internal to and affecting the place itself. Some of the problems might be different today compared to the 1920 s, but they remain issues that require a form of regional response. The regional is a vital and convenient tier of strategic planning and will remain so, even if identifying an appropriate spatially fixed administrative and democratic fit between the national and the local is often an unobtainable task.

In the twenty first century, the case for regional planning is set against a backdrop of politically unfavourable large units of subnational government, weak democratic accountability and legitimacy, subnational plans that take an eternity to prepare, and the bypassing of subnational strategies in practice by more immediate ad hoc spatially-selective national responses. Having a regional plan might now be seen as something of a luxury. And so, a critical question remains: can the region ever be planned and, if so, what future form should regional planning take?

\subsection{Recognising the fragmented and multiple agency landscape of planning}

Cities and regions are becoming increasingly complex, technologically-driven, and difficult to plan for with any degree of certainty. The world faces an array of crises, from economic uncertainty, demographic change, climate change and extreme weather events, greater social polarisation, and political turbulence. The impact of these changes will be difficult to ascertain and the resultant disruption these will have on places in the immediate future and longer term. But we do know the changes will have geographical implications for different settlements in the same region. We will need to address the spatial implications of climate change, flooding and the loss of habitat. We will continue to address the economic fate of places as global trade patterns affect business relocation, failure and growth, and nation states financial stability fluctuate. We remain appalled at harrowing stories of social exclusion, poverty levels, the left behind, the fate of migrants and populist attitudes towards different groups in society. We marvel at the availability of technology 
to compress time and space, instantly at our finger tips. We can celebrate all that is unique about places that make them attractive, or historic, or worth protecting or visiting.

It goes without saying that researchers and practitioners with advanced knowledge and understanding of urban and regional change recognise that all of these trends affect spatial change in different ways, within the same country, within a city, between cities, between urban and rural, and how different sectoral changes affect other sectors. How often do we lament also at the continuing failings of government to address issues, in a timely way, even when evidence is presented. We become frustrated at the misalignment between different public and private agencies responsible for service or policy delivery in different places. We criticise political institutions and multinationals for their lack of transparency in how they make decisions that affect cities and regions in the present and long term. And we become agitated with the arrogance of government bodies in how they exclude the subjects they are supposedly answerable to.

In place of larger units of sub-national government, that are either being abolished or at least subjugated, an array of agencies now jostle to perform tasks that might otherwise have lay at the door of regional planners and regional government. Utility companies responsible for energy and water are often privatised companies, controlled by multinationals; transport services are in the hands of a multitude of state and business interests, with a lack of integration between transport infrastructure sunk costs and the provision of different modes of public transport services; health services and education provision are shaped by more localised governance forms; economic development policy might be instigated by more-than-local agencies in an era of inter-place competition; and development itself is increasingly determined by real estate market interests where meeting demand will generate the best financial returns (Pike et al., 2019; Raco \& Savini, 2019). An individual region in the 2020s might have dozens of different types of agencies public, private, public-private, governance, government taking critical decisions that shape the future 
spatial form of the regional area. This is a recognition of how difficult it now is to have any form of regional coordination and regional alignment of strategic investment decisions across a myriad of vested interests.

Not only have we forgotten about the original twentieth century intention of having regional planning (i.e. it exists only where it is needed), we have ended up with a lamentable substitute for it in the twenty first century. Addressing regional problems is not only resolved by new nationallydetermined infrastructure spending. Nor is it addressed by simply having a regional plan. Technology and climate change, global trade and world social mobility, occurring rapidly and disruptively, have all made the task of institutionalised and siloed regional planning a difficult endeavor. The result has been for regional planning exercises, where they still exist, to retrench into focusing on narrow growth and infrastructure matters but with little political force over the real agencies of change. The twentieth century tools we once relied upon cannot be used today to address such critical issues as interregional differences, the relationships between capital cities and second tier urban regions, and the vulnerability of parts of a region to rising sea levels or drought or wildfires. Some may use that as an argument to abandon planning altogether, an approach some politicians have used to justify the removal of those institutionalised and bureaucratic standard regional forms. But, rhetorically, do we still not need to identify what is happening at a regional scale, by analysing changes, coordinating responses, mapping vulnerabilities and opportunities, and delivering political programmes of action?

\subsection{Embracing and promoting the unique qualities and attributes of planning}

Not having regional planning apparatus does not equate to not having regional planning. Here we need to think less of late twentieth century regional planning as regional plans and regional 
institutions. Rather, we need to think of regional planning as an enduring set of attributes and qualities, a toolkit of perspectives, knowledges, skills and methods that are still available to address regional issues and problems. The world has moved on; there is little point at lamenting about past forms of regional planning that are probably no longer fit for purpose to address the changing and changeable forms of both sub-national and more-than-local spatial and economic trends. To be effective and relevant to the twenty first century, regional planning does not need to be constrained within past institutional shackles. Planners are still likely to have to identify and manage a whole host of economic, environmental and infrastructural issues that affect large geographical areas with or without regional-wide government and regional plans.

The future impact of new forms of design, technology, the impact of new infrastructure, new patterns of living and working, and the digital dynamics that affect every aspect of our world will need assessing and monitoring. Regional impacts will still accrue from the growth of megalopolis sprawling outwards and pointing skywards, and future changes in transportation will impact upon commuting times, work-home and livability patterns, and logistic flows and trading routes between places. Thinking in the context of the next decade or more, these trends might not cause the development of new ideal planned cities, imposed in a top-down way politically and professionally, but rather the acceleration of urban agglomerations over much greater physical distances at the megapolitan or megaregion scale (Friedmann \& Sorensen, 2019). The regional externalities are likely to be significant.

The twenty-first century smart cities debate, for example, and the development of an Internet of Things that embeds digital technology in the life and design of cities, is but the latest series of inventions that will have far reaching consequences for the way we plan, manage, and govern future regions and cities (Batty, 2013). How this will happen is more uncertain. We know technologists are advancing innovations that can benefit the future management of regions at a 
bewildering pace; we also know that social scientists can be sceptical of the advancement of digitisation and the impact it has on political accountability, democratic transparency, and social inclusion. In 2017, for example, Sidewalk Labs started undertaking a planning experiment to redevelop part of the Toronto Waterfront as a testbed for developing future planning ideas based on the smart city model and the notion of 'building a city from the internet up', however, it has drawn criticism over concerns relating to data privacy and how embedding a technical product in a government system leaves the state ever-more dependent on a corporation - in this case Alphabet Inc., the parent company of Google. Meanwhile, cities such as Hangzhou and Suzhou are using Chinese retail giant Alibaba's Urban Cloud City Brain to coordinate traffic light signalling to reduce overall congestion and give emergency response vehicles priority passage from the point of dispatch to the site of emergency, but accompanying this are concerns about data privacy breaches, increased surveillance and dependence on a single centralized system were it to fail or be hacked.i. This means places are likely to be increasingly difficult to manage and regulate in traditional ways, at least using tools and processes that were designed in another era with set institutions and defined roles and attributes that are all increasingly uncertain. In this context, it is not the future form of regional planning that we should be concerned about, but rather how cities within regions will become the intersections of a host of global and local flows and the physical embodiment of continual spatial churn (Batty, 2020).

\subsection{Forging multiple and fluid planning frames}

In the future, who will take responsibility for assessing these trends, analysing their impact, monitoring spatial differentials, modelling dynamic change, establishing the case for intervention, communicating options, and presenting the intelligence to politicians and others? There is a role here for regional planning; not regional planning as we witnessed in the last century, but regional planning as a suite of methods, data and processes, interlinked and aligned, and undertaken by a range of organisations. There will remain an even greater need to create processes of 
legitimation and regulation to deal with the impacts and costs of externalities, allowing individuals, communities and businesses voices in dynamic regional change, and communicating spatial change through visual and verbal means. Previous forms of regional planning, even using simple territorial maps, are not going to be adequate for this task. Even twentieth century forms of governance and democracy are not necessarily fit for purpose.

Data on everything, from transport usage, air pollution and flood risk, to pedestrian footfall and energy usage, is produced from sensors placed in urban and regional locations, generated by the second, and immediately accessible to anyone who wishes and is able to see that data. Long gone are the days when such survey data would only be available to and analysed periodically by the professional planner, creating options and published through successive drafts of a plan before their official release to everyone else some years down the line. New technology, coupled with the different digital ways people interact with agencies, makes the case for a different style of regional planning. Future forms of regional planning are required that are responsive to development opportunities but also ones that are capable taking on board a myriad of intelligence and data flows, multiple forms of citizen and business interaction, and a plurality of planning organisations beyond elected government (Raco \& Savini, 2019).

The early twentieth century guise of regional planning focused on the picture of economic disadvantage in distinct places. The focus was very much on the perspective: identifying the causes of the problem and bringing about an agreed plan of action. In the middle of the twentieth century, as the case for regional planning to address spatial unevenness in individual nations became a cause celebre, so the focus began to consider not only the content but also the frame of the picture, to give it a robust political and institutional status. By the latter part of the twentieth century, continual academic and governmental attention focused overtly on the pictures frame finding the right regional institutional fix - so much so that the real reasons for having regional 
planning - to address significant regional sector problems - were relegated. In the first two decades of this century, not only has the frame for the regional planning picture been largely abandoned, so too has any effective national political commitment to address regional differentials and unevenness (Allmendinger, 2016). We have, in essence, the worst of all worlds, fragmented agencies working to different agendas, duplicating responsibilities and tasks, growing social and economic disparities both within and between regions, the rise of a data-driven world recording urban and regional trends, but lacking any coherent way to assess and analyse the dynamic changes as they are occurring, absence of a platform for regional dialogue and debate. Not only is the regional planning frame being eroded, the regional picture is increasingly pixelated and fuzzy.

The content of the regional picture needs to be captured systematically, and presented visually and accessibly to wider audiences. The data and digital tools increasingly available need to be harnessed as a continuous and enduring set of accessible and interpreted spatial analysis, not only led and controlled by technologists, but utilised by spatial strategists and social scientists and available to all. Regional planning would not take on a static form, but rather become a fluid and changeable process, a continual cycle of regional study, that brings focus to the regional picture. The frame remains important politically and legitimately to further selective intervention and project development, allocate future resources, provide accountability for action, and communicate change to foster greater understanding, but the frame may take on multiple forms by a range of actors through checks and balances (Valler \& Phelps, 2018). This would give rise to a 'pragmatic' form of regional planning (cf. Healey, 2009), adaptive and agile to the needs of individual regions, sensitive to individual places and trends, and response to the various agencies operating in any one region. It is also one that is suitable for a more complex and fast-paced world. 


\subsection{Repositioning the planner as an orchestrator and enabler of planning}

regional futures

A future form of regional planning will need to attach less importance to a plan as a physical, allencompassing entity and more to the need to align different types of spatial intelligence across various organisations (Batty, 2018). Regional planning's future could well be centred on achieving spatial alignment in a fragmented and highly diffuse landscape, performed with agility according to need and opportunity, but also adaptive to place distinctiveness and audience. How that would be achieved, by necessity, would be different in different regions, and possibly different within different parts of a region. But it is important to reiterate here that these tasks are, and always have been, essentially planning skills, irrespective of what sort of organisation any one planner works within.

The traditional regional planning process, as we see it, still exists. This is the one that identifies the problem or trend, gathers data and analyses it, understands it, proposes a solution or solutions, manages delivery on the agreed one, and finally evaluates. The problem for planning is that while in the mid-twentieth century heyday of regional planning it was a single group of professional planners taking it all the way through, the first parts of the process have now been lost with the advent of real-time modelling. The result is that planners have ended up focusing on the delivery, all the time becoming increasingly detached from engaging with the new actors in a continual dialogue.

Our strong contention is that planning regional futures lay firmly in the latter. Traditional planning skills appeared linear in Geddes' inspired model of Survey Before Plan, taken forward by Patrick Abercombie (1933) and a theme for planning in the interwar years (Figure 1a), through to a more circular but still linear model of Identify $\rightarrow$ Gather $\rightarrow$ Analyse $\rightarrow$ Deliver $\rightarrow$ Evaluate by the mid- 
to-late twentieth century (Figure 1b), where planning became focused on the need to prepare and implement a blueprint for some desired end state. Indeed, this linear approach still remains prevalent today with Beauregard (2020), for instance, proposing Knowing $\rightarrow$ Engaging $\rightarrow$ Prescribing $\rightarrow$ Executing as the foundations of planning. We take a different approach, suggesting a suite of planning skills which, as time marched on and cities and regions became more complex, have increasingly required planners (professional or otherwise) to be adept at juggling:

- Asset Assessment: the ability to understand how places and territories are changing, identifying the unique circumstances that have shaped spatial change over time and their legacy for the present and the future, and the challenges and opportunities that individual territories possess. The legacy issue, combined with present circumstances, creates a unique place make-up that may lead to the identification of territorial or place assets. This is an early planning skill most neglected, focusing on place need rather than institutional need, and might cover, for example, regional resilience (Christopherson et al, 2010) or the potential for regions of high speed rail routes (Vickerman, 2015).

- Synopsis \& Political Astuteness: the need to take different sectors as they are driving regional change and relate them to each other, beyond single policy and agency perspectives, by taking a synoptic perspective of how regions are changing over time (Cejudo and Michel, 2017). This need for this planning skill has been exacerbated over the last 40 years by increasing governance framgentation and multiple agency involvement in regional change. This includes identifying the cumulative spatial effects of multiple drivers of change over, and in, specific territories, and assessing the possible domino spatial effects caused by a sequence of events over time - both unforeseen or foreseeable, such as global financial shocks - and how they might be brought to bear on 
a single place. It also includes the need for political astuteness (Tewdwr-Jones and Goddard, 2014).

- Analysis \& Synthesis: the ability to undertake and commission spatial data and trends relating to how places change over time, through backcasting to the previous period of time and through scenario planning by projecting forward how changes may accrue in the future and relate these to specific geographical areas. This might involve, for example, demographic and migration trends (Giannakouris, 2010) and regional skills development (Glaeser et al, 2014). The planning skill here is to analyse and combine different data sets and intelligence, often from different sources, through synthesis for the same region, leading to a suite of options for discussion and decision-making.

- Alignment \& Integration: the need to bring together all necessary agencies from different sectors to prepare a jointly-agreed project plan for a region or sub-region, or deliver a programme of spatial development change. This new planning skill is required to align different agencies, through programme management, and requires an understanding of the agencies' different remits and expectations, but also an enduring search for common ground to achieve results. Typical needs revolve around, for example, delivering low carbon transport (Gray et al, 2016) or linking water supply with housing growth (Hanak and Browne, 2008). Integration implies a bonding between agencies that might, in turn, compromise the independence of a participating agency; alignment implies a temporal or enduring ability to 'making sense together' (Healey, 1992) without transformational change of participating agencies.

- Phasing \& Temporality: a requirement to recognise the spatial, territorial and developmental sequencing of discussion, analysis, implementation across and between 
relevant agencies in order to manage change and delivery expectations. In planning terms, this may involve progressing results for $x$ and $y$ before $z$ can be achieved, and is common for large scale infrastructure projects, landownership and land assembly overcoming legal obstacles, or even financing. Examples could include the phasing out of internal cumbustion engine vehicles in cities and regions (Glazebrook and Newman, 2018), or meeting the needs of age-friendly cities (Buffel and Phillipson, 2016). Skill requirements involve a recognition of the importance of phasing and time sequencing in long term programme planning.

- Mediation: the need to align different agencies to reach a relatively common position to deliver an outcome or position; mediation may be an enduring process of negotiation and compromise or a one-off process for a specific project. This is a planning skill that has developed in need and importance over time as the number of relevant agencies that contribute to, deliver or shape spatial change has increased. An example might be the need to deliver logistic services around port and airport in the context of urban expansion plans, property investment, and global trade deals (Hesse, 2016).

- Communication: the requirement to explain and disseminate aspects of urban and regional change to interested agencies and organisations as they affect places. Traditionally, regional planning communication has occurred through a regional spatial plan or policy framework, accompanied by a spatial schematic or map highlighting principal geographical features and possible changes. More lately, communication can be achieved through social media and digital form or representation, and can be much more instantaneous. Communication also refers to the skill of achieving communicable interaction between different actors within a regional space that have a vested interest in 
regional change (Wilson and Tewdwr-Jones, 2019), tasks that planners themselves may find challenging.

- Visualisation: whereas planning has traditionally relied on preparing and disseminating a two-dimensional map or schematic that identifies physical places by the plan-making agencies, visualisation may refer to any form of media - by recovering illustration, film and animation, and embracing dashboards, virtual reality and cyberspace - that is able to represent and communicate spatial change and analysis and employed as a device by any interested organisation (Stehle \& Kitchin, 2020). This includes recent examples in developing digital twins for metropolitan regions (Mohammadi and Taylor, 2017), and these skills are not necessarily held by professional planners but rather by computer scientists.

This is by no means an exhaustive or even definitive list of skills, but it does present a different way of envisaging planning in and for the twenty-first century, with the planner assuming the role of orchestrator and enabler of planning regional futures ${ }^{i i i}-$ a notable contrast with the 'planners as leaders' rhetoric we have grown accustomed to (Neuman, 2019).

We could look at these as being new planning skills, necessity skills for (securing planning's and planner's role in) planning regional futures. Yet, what is clear, from our perspective, is that some of these skills have not necessarily changed, but have been freed up from institutionalised regional planning, evolving quickly such that traditional approaches to these skills are being left behind, and with it planners and planning as we have to come to identify them. Another way is to view them as the unique planning skills, a modern take on the essence of planning as it was always envisaged and conceived to be all those years ago, and which today provides the pillar on which to reassert the key role of planning in regional futures. Yet, what is clear, again from our 
perspective, is that these skills are not unique to planning. There is no reason why some of the individual skills cannot be done - indeed are already being done - by actors other than planners. What we are clear on is that the ability to understand all these skills simultaneously and to deploy them when required is a unique planning skill (Figure 1c). For us this is the fundamental pillar on which planning regional futures can, and should, be centred. The ways these skills interact and are brought to bear with each other in territories and places are unique, with the skill of the planner to tacitly know when to use which specific skill(s). Why this is important for regional studies is because it differentiates regional planning skills and knowledge as a unique set when compared to more generic planning skills, something which has implications for the study skills we teach as well as practise professionally (cf. American Planning Association, 2020; Green Leigh et al., 2019; Sandercock, 1997). Allied to this, other accounts of planning skills are determined by theorising planning differently, leading to a different emphasis on the role of the planner and by implication a different taken on the planning skills required (cf. Ozawa \& Seltzer, 1999; Alexander, 2001), whereas our primary focus is thinking more generally about planning and regions per se.

Our final point here is that these skills are not directly dependent on and subservient to governance forms. Although they may become functions of government agencies, they can exist and be pursued outside of bounded institutions or government. Recognising the rise and fall, ebb and flow, of traditional regional planning was to all intents and purposes dictated by the whims of local and national government, securing a future for regional planning which is dependent on and subservient to governance forms is increasingly risky, especially in these turbulent political and economic times. Our proposition here is that the regional planning will always have important connection to formal structures and frameworks of government but planning regional futures will increasingly centre on consortia of willing actors bringing their skills, competencies and resources to bear on trying to address those wicked problems affecting cities and regions. Planning and 
planners can have a key role to play in this new landscape, but it is one they must grasp. Planning's origins lay here, so why not its future?

\section{Conclusion: An Introduction to a Debate on Planning}

\section{Regional Futures}

The aim of this paper is to re-energise planning debates in regional studies. For our part we approach this as firm believers in the function of regional planning, but not the form that regional planning generally takes. In this paper we make the case for recovering the purpose of regional planning as an approach and skillset for addressing regional needs in a place-specific way. This stands in opposition to the type of standardised institutionalised forms and one-size-fits-all solutions which have become the hallmark of regional planning, but increasingly resented for undermining place distinctiveness and divorced from addressing regional needs. The role of planning in addressing regional place-specific needs, rather than the future form of regional planning, is the terrain on which planning regional futures should be debated.

So why do some nations still persist with 'old-style' regional planning? Or, for nations that have abolished regional plans, why do some crave their return? We can identify several reasons:

- Asserting higher-level control: through requirement from higher tiers of the state that might include the allocation of central resources on a regional scale; devolving responsibility (and therefore blame) to subnational government to shape more localised spatial arrangements particularly on contentious matters; to fulfil international goals (e.g. SDG11), requirements (e.g. administering European funds) and agendas (e.g. New Urban Agenda). 
- Nostalgia: a longing for stability and certainty through neat defined regional planning forms, situated within clear administrative hierarchies, delivering (at least on paper) territorial synchronicity, and yearning for legitimating planning, planners and plans, irrespective of whether they actually deliver or not.

- Filling the void: a desire or requirement to redress a perceived or actual democratic, accountability or transparency deficit of policy making and decision making below the level of the nation state and above localities, with an attraction to administratively and politically determined arrangements.

The problem is that this amounts to fiddling (with the planning 'frame') while Rome (the 'picture' of who and where is being planned for) burns.

We do not need old solutions to new problems, but new approaches for addressing wicked regional problems (both old and new). As firm believers in the purpose and values (but not the current form) of regional planning and the need to recover its raison d'être, we must first see regional problems for what they are - heterogeneous. Wicked problems never go away and it is the essence of planning to deal with them. But besides recognising the heterogeneity and wickedness underlying these problems, planning regional futures needs to roll out in accordance with certain parameters characterised by adaptability and flexibility, not one-size-fits-all parameters. Many geographical contexts are already witness to this, with a growing nexus between community activists and businesses with or without the local authorities interfering or mediating. Our argument is that the future (and indeed the present) rests in multiple forms of planning - one of which may in certain circumstances and contexts be something akin to 'oldstyle' regional planning, but are more likely to include a diverse range of increasingly ad hoc and agile planning measures, delivering change, and shaping future cities and regions - which implies multiple forms of legitimacy, accountability and democratic transparency. In short, the question 
we pose for anyone reading this is: Are we prepared to acknowledge and engage? If not, can Planning (as both a profession and discipline) remain legitimate if we fail to respond?

\section{Acknowledgements}

The paper has benefitted from feedback received at various international conferences, research seminars, as well as very constructive feedback from external reviewers and the editors of the journal. 


\section{References}

Abercrombie, P. (1933). Town and Country Planning. London: Thornton Butterworth.

Alexander, E. (2001). What do planners need to know? Journal of Planning Education and Research, 20, 376-380.

Allen, J., Cochrane, A., \& Massey, D. (1998). Rethinking the Region. London: Routledge.

Allmendinger, P. (2016). Neoliberal Spatial Governance. London: Routledge.

Allmendinger, P. (2017). Planning Theory. London: Palgrave Macmillan.

Allmendinger, P., \& Haughton, G. (2007). The fluid scales and scope of UK spatial planning. Environment and Planning A, 39, 1478-1496.

Allmendinger, P., \& Haughton, G. (2019). Opening up planning? Planning reform in an era of 'open government'. Planning Practice \& Research, 34, 438-453.

American Planning Association (2020). What Skills Do Planners Need? Available @ https://www.planning.org/choosingplanning/skills/

Batty, M. (2013). Big data, smart cities and city planning. Dialogues in Human Geography, 3, 274279. 
Batty, M. (2020). How disruptive are new urban technologies? Environment and Planning B, 47, 3-6.

Brenner, N. (2003). Metropolitan institutional reform and the rescaling of state space in contemporary Western Europe. European Urban and Regional Studies, 10, 297-324.

Brenner, N. (2019). New Urban Spaces. Oxford: Oxford University Press.

Buffel, T. \& Phillipson, C. (2016). Can global cities be 'age-friendly cities'? Urban developments and ageing populations. Cities, 55, 94-100.

Cejudo, G. \& Michel, C. (2017). Addressing fragmented government action: Coordination, coherence, and integration. Policy Sciences, 50, 745-767.

Christopherson, S., Michie, J. \& Tyler, P. (2010). Regional resilience: theoretical and empirical perspectives. Cambridge Journal of Regions, Economy and Society, 3, 3-10.

Counsell, D., \& Haughton, G. (2003). Regional planning tensions: planning for economic growth and sustainable development in two contrasting English regions. Environment and Planning $C$, $21,225-239$.

Davoudi, S. (2012). The legacy of positivism and the emergence of interpretive tradition in spatial planning. Regional Studies, 46, 429-441.

Fainstein, S. \& DeFilippis, J. (Eds.) (2016). Readings in Planning Theory. Chichester: WileyBlackwell. 
Friedmann, J. (1963). Regional planning as a field of study. Journal of the American Institute of Planners, 29, 168-175.

Friedmann, J. (1993). Toward a non-Euclidian mode of planning. Journal of the American Planning Association, 59, 482-485.

Friedmann, J. (2019). Thinking about complexity and planning. International Planning Studies, $24,13-22$.

Friedmann, J., \& Sorensen, A. (2019). City unbound: emerging mega-conurbations in Asia. International Planning Studies, 24, 1-12.

Friedmann, J. \& Weaver, C. (1979). Territory and Function: The Evolution of Regional Planning. Berkeley, CA: University of California Press.

Galland, D. (2012). Is regional planning dead or just coping? The transformation of a state sociospatial project into growth-oriented strategies. Environment and Planning C, 30, 536-552.

Galland, D., Harrison, J., \& Tewdwr-Jones, M. (2020). What is metropolitan planning and governance for? In, Zimmermann, K., Galland, D., \& Harrison, J. (Eds.) Metropolitan Regions, Planning and Governance. Berlin: Springer pp. 237-256.

Geddes, P. (1915). Cities in Evolution. London: Williams \& Norgate. 
Giannakouris, K. (2010). Population and social conditions: Eurostat Statistics in focus 1/2010. Luxembourg: Eurostat.

Glaeser, E.L., Ponzetto, G.A.M. and Tobio, K. (2014). Cities, skills and regional change. Regional Studies, 48, 7-43.

Glasson, J. (1978). An Introduction to Regional Planning. London: Hutchinson.

Glazebrook, G. \& Newman, P. (2018). The city of the future. Urban Planning, 3, 1-20.

Gray, D., Laing, R. and Docherty, I. (2016). Delivering low carbon urban transport choices: Euroean ambition meets the reality of institutional (mis)alignment. Environment and Planning $A$. 49, 226-242.

Green Leigh, N., French, S., Guhathakurta, S., \& Stiftel, B. (Eds.) (2020). The Routledge Handbook of International Planning Education. London: Routledge.

Gunder, M., Madanipour, A., \& Watson, V. (Eds.). (2018). The Routledge Handbook of Planning Theory. New York: Routledge.

Hall, P. (2014). Cities of Tomorrow. $4^{\text {th }}$ edition. Oxford: Blackwell.

Hall, P. \& Tewdwr-Jones, M. (2020). Urban and Regional Planning (6 $6^{\text {th }}$ Edition). London: Routledge. 
Hanak, E. \& Browne, M. (2008). Linking housing growth to water supply: new planning frontiers in the American West. Journal of the American Planning Association, 72, 154-166.

Harrison, J. (2020). Seeing like a business: rethinking the role of business in regional development, planning and governance. Territory, Politics, Governance DOI: $10.1080 / 21622671.2020 .1743201$

Haughton, G., \& Counsell, D. (2004). Regions, Spatial Strategies and Sustainable Development. London: Routledge.

Healey, P. (1992). Planning through debate: the communicative turn in planning theory. Town Planning Review, 63, 143-162.

Healey, P. (2007). Urban Complexity and Spatial Strategies. London: Routledge.

Healey, P. (2009). The pragmatic tradition in planning thought. Journal of Planning Education and Research, 28, 277-292.

Hesse, M. (2016). The City as a Terminal: The Urban Contexts of Logistics and Freight Transport. London: Routledge.

Howard, E. (1902). Garden Cities of Tomorrow. London: Faber \& Faber.

Knaap, G.J., Nedovic-Budic, Z., \& Carbonell, A. (2015). Planning for States and Nation States in the US and Europe. Cambridge: Lincoln Institute of Land Policy. 
Kuklinski, A. R. (1970). Regional development, regional policies and regional planning: problems and issues. Regional Studies, 4, 269-278.

Mohammadi, N. and Taylor, J. (2017). Smart city digital twins. 2017 IEEE Symposium Series on Computational Intelligence (SSCI). Honolulu, SSCI, 1-5.

Murat Güney, K., Keil, R., \& Ucoglu, M. (Eds.) (2019). Massive Suburbanization: (Re)building the Global Periphery. Toronto: University of Toronto Press.

Neuman, M. (2020). Leadership. In, Green Leigh, N., French, S., Guhathakurta, S., \& Stiftel, B. (Eds.) The Routledge Handbook of International Planning Education. London: Routledge, pp. 174-183.

Ozawa, C., \& Seltzer, E. (1999). Taking our bearings: mapping a relationship among planning practice, theory, and education. Journal of Planning Education and Research, 18, 257-266.

Paasi, A., Harrison, J., \& Jones, M. (2018). 'New consolidated regional geographies', in Paasi, A., Harrison, J., \& Jones, M. (Eds.) Handbook on the Geographies of Regions and Territories. Cheltenham: Edward Elgar, pp.1-20.

Paasi, A., \& Zimmerbauer, K. (2016). Penumbral borders and planning paradoxes: relational thinking and the question of borders in spatial planning. Environment and Planning A, 48, 75-93.

Pike, A., O’Brien, P., Strickland, T., \& Tomaney, J. (2019). Financialising City Statecraft and Infrastructure. Cheltenham: Edward Elgar. 
Raco, M., \& Savini, F. (Eds.) (2019). Planning and Knowledge: How New Forms of Technocracy are Shaping Contemporary Cities. Bristol: Policy Press.

Roodbol-Mekkes, P. H., \& van den Brink, A. (2015). Rescaling spatial planning: spatial planning reforms in Denmark, England, and the Netherlands. Environment and Planning C, 33, 184-198.

Sandercock, L. (1997). The planner tamed: preparing planners for the twenty first century. Australian Planner, 34, 90-95.

Savini, F., \& Aalbers, M. (2016). The de-contextualisation of land use planning through financialisation: urban redevelopment in Milan. European Urban and Regional Studies, 23, 878894.

Schindler, S., \& Kanai, J-M. (2019). Getting the territory right: infrastructure-led development and the re-emergence of spatial planning strategies. Regional Studies, DOI: $10.1080 / 00343404.2019 .1661984$

Stead, D. (2012). Best practices and policy transfer in spatial planning. Planning Practice and Research, 27, 103-116.

Stehle, S., \& Kitchin, R. (2020). Real-time and archival data visualisation techniques in city dashboards. International Journal of Geographical Information Science, 34, 344-366.

Storper, M. (2016). The neo-liberal city as idea and reality. Territory, Politics, Governance, 4, 241263. 
Tewdwr-Jones, M. (2012). Spatial Planning and Governance. London: Palgrave Macmillan.

Tewdwr-Jones, M. \& Goddard, J. (2014). A future for cities? Building new methodologies and systems for urban foresight. Town Planning Review, 85, 773-94.

UN-Habitat (2017). New Urban Agenda. Nairobi: UN-Habitat.

Valler, D., \& Phelps, N. (2018). Framing the future: on local planning cultures and legacies. Planning Theory \& Practice, 19, 698-716.

Vickerman, R. (2015). High speed rail and regional development: the case of intermediate stations. Journal of Transport Geography, 42, 157-65.

Watson, V. (2009). Seeing from the South: refocusing urban planning on the globe's central urban issues. Urban Studies, 46, 2259-2275.

Watson, V. (2019). The return of the city-region in the new urban agenda: is this relevant in the Global South? Regional Studies, DOI: 10.1080/00343404.2019.1664734

Wilson, A. \& Tewdwr-Jones, M. (2019). Let's draw and talk about urban change: Deploying digital technology to encourage citizen participation in urban planning. Environment and Planning B, DOI: 10.1177/2399808319831290

Wu, F. (2015). Planning for Growth: Urban and Regional Planning in China. London: Routledge.

Rydin, Y. (2011). The Purpose of Planning. Bristol: Policy Press. 
' Of note is how Paasi, among others, is commonly referring to slow long-term processes of region building, something which increasingly runs counter to the dynamic short-term churn of present-day regional planning imaginaries.

ii At the time of writing, Alibaba's City Brain is operating in 23 cities (22 in China plus Kuala Lumpur in Malaysia), serving customers in 48 different specific application scenarios across 11 major areas of city life, including transportation, urban government, cultural tourism, and health.

iii This list results from ongoing discussion between the authors, drawing in particular on: the findings of major research projects examining digital means of planning urban and regional futures (Tewdwr-Jones), international comparative planning (Galland) and private actors in planning (Harrison); roles as Director of a Future Cities Urban Living Partnership 2015-2019 working across public, private and voluntary sectors to deliver projects in Newcastle-Gateshead (Tewdwr-Jones) and Chair of the Association of European Schools of Planning (AESOP) Excellence in Education Board (Galland); and, collective participation in a three-year international working group examining the planning and governance of metropolitan regions (2016-2019, all authors). 
Figure 1: Evolving approaches to regional planning and professional planning skills

Figure 1a: Regional planning in the interwar years

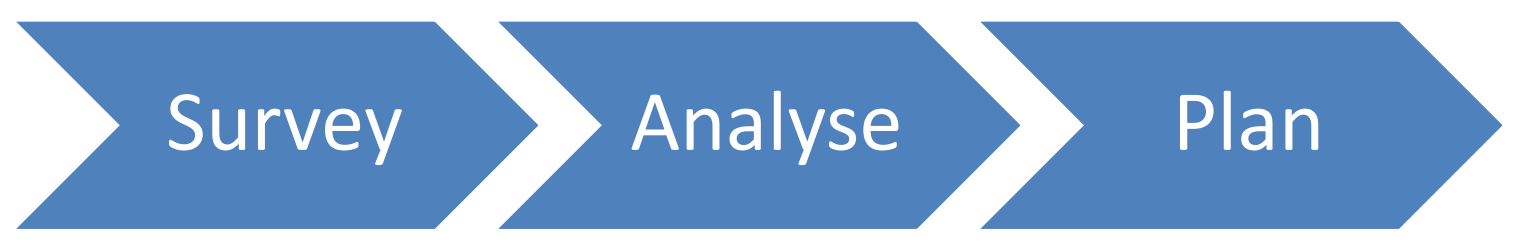

Figure 1b: Regional planning in the postwar years

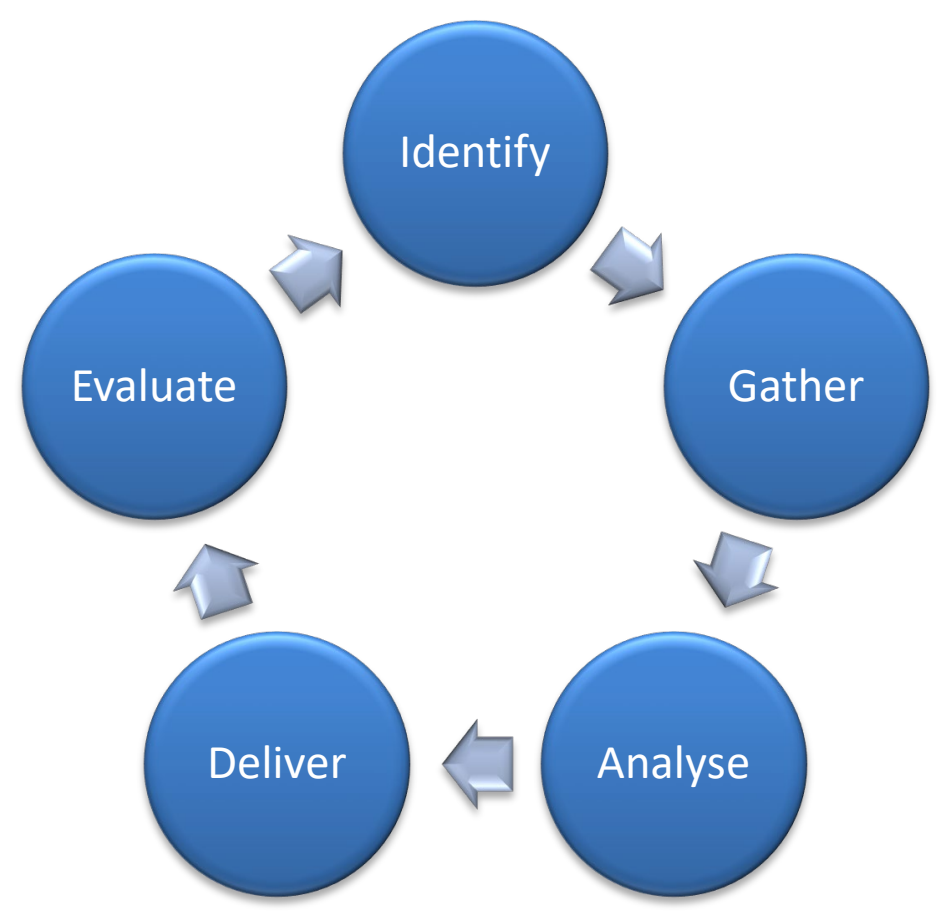


Figure 1c: Skills for planning regional futures

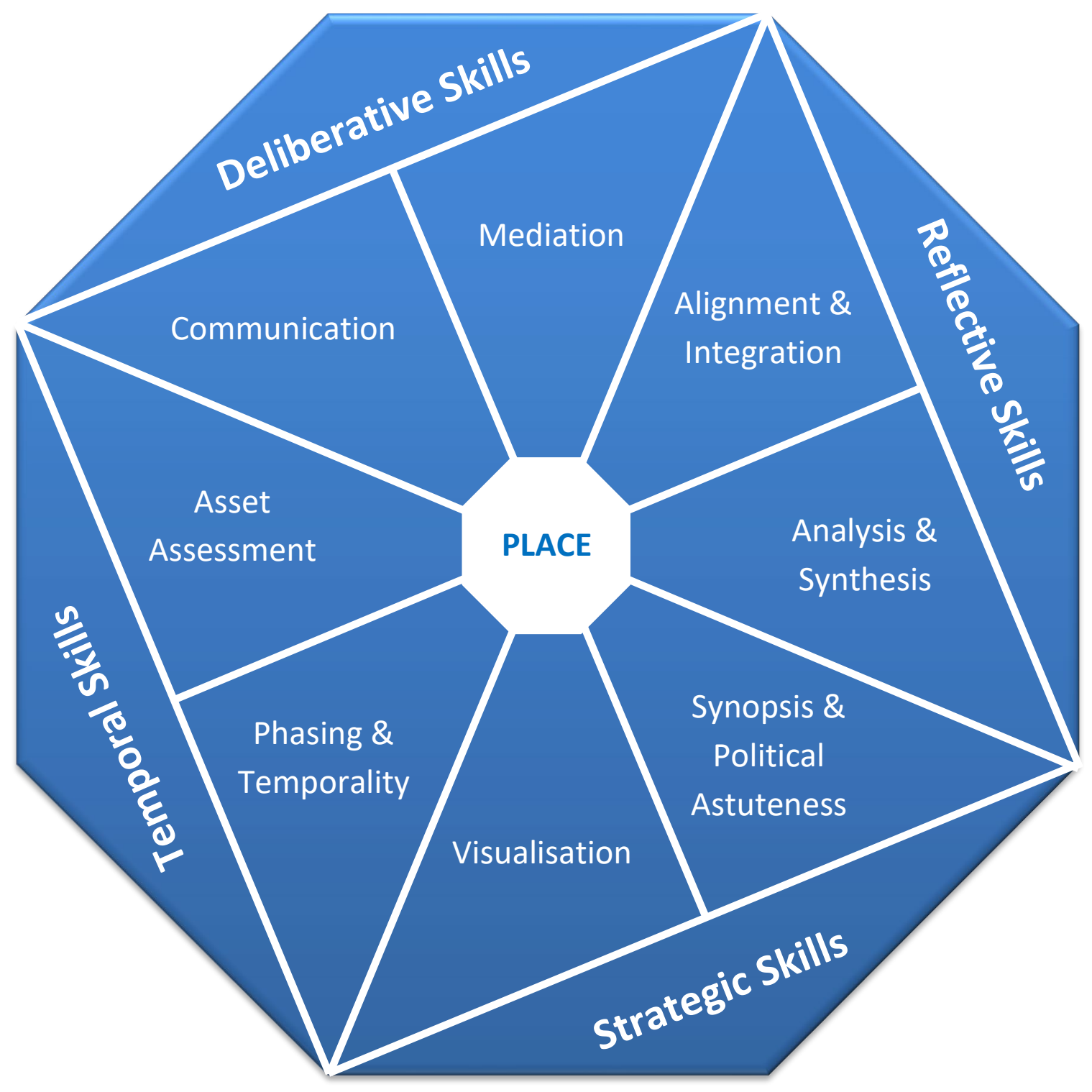

